\title{
Anaemia: Approach to diagnosis (part 2)
}

\author{
N Alli, ${ }^{1}$ MB BCh, FCPathHaem (SA); J Vaughan, ${ }^{1}$ MB BCh, FCPathHaem (SA), MMed (Haem); \\ M Patel, ${ }^{2} \mathrm{MB}$ ChB, FCP (SA), MMed, FRCP (Lond), PhD \\ ${ }^{1}$ Department of Molecular Medicine and Haematology, School of Pathology, Faculty of Health Sciences, University of the Witwatersrand, \\ Johannesburg, and National Health Laboratory Service, Johannesburg, South Africa \\ ${ }^{2}$ Department of Clinical Haematology, Division of Internal Medicine, Chris Hani Baragwanath Academic Hospital, Johannesburg, \\ and School of Medicine, Faculty of Health Sciences, University of the Witwatersrand, Johannesburg, South Africa
}

Corresponding author: N Alli (nazeer.alli@nhls.ac.za)

\begin{abstract}
Anaemia is defined as a condition in which the number of red cells or their oxygen-carrying capacity is insufficient to meet physiological needs. It is the most common disorder globally and one of the conditions that general practitioners most frequently encounter. In the World Health Organization global database, anaemia is estimated to affect 1.6 billion people. Anaemia may result from $(i)$ decreased bone marrow output; or ( $\mathrm{ii}$ ) peripheral loss, destruction or sequestration of red cells. As anaemia manifests in a whole range of conditions, it is important to embrace a structured diagnostic approach. The recommended approach incorporates clinical and pathophysiological considerations, red cell characteristics, and bone marrow activity. Causes of anaemia related to decreased bone marrow output have been discussed in the previous issue of $S A M J$, in the first part of this two-part series. The focus of the current article is on peripheral causes of anaemia.
\end{abstract}

S Afr Med J 2017;107(2):96-100. DOI:10.7196/SAMJ.2017.v107i2.12223

This article is the second of a two-part CME series on anaemia

According to the World Health Organization (WHO), anaemia is defined as a condition in which the number of red blood cells or their oxygen-carrying capacity is insufficient to meet physiological needs, which vary by age, sex, altitude, smoking, and pregnancy status. ${ }^{[1]}$

The causes of anaemia are divided into two broad categories (Fig. 1):

- Central: decreased bone marrow production/output of red blood cells, discussed in part 1 of the CME series on anaemia. ${ }^{[2]}$

- Peripheral: loss or destruction of red cells through haemolysis, bleeding or splenic sequestration, which is the subject of discussion in this issue.

While the two categories form a sound basis for diagnostic work-up, they are not mutually exclusive. As a rule, a good reticulocyte response essentially excludes bone marrow failure. However, a combination of the two categories may give mixed signals that could present a confusing picture. By way of example, uncomplicated haemolysis with normal bone marrow function invokes a brisk reticulocyte response in the initial stages (Fig. 1), but with time, as folate is lost and stores are depleted, the response is blunted owing to ineffective haematopoiesis.

\section{Haemolysis}

Haemolysis is defined as the premature destruction of red cells. The lifespan of normal red cells is 100 - 120 days.
Haemolysis is classified as:

- intravascular, where red cells are destroyed within the vascular compartment

- extravascular, where red cells are destroyed outside the vascular system by macrophages.

It is important to understand the pathophysiology of the two categories of haemolysis, as clinical manifestations and treatment principles differ in the two types (Table 1).

\section{Intravascular haemolysis}

Red cells break up within the vascular compartment and its contents are released into the circulating plasma. Free $\mathrm{Hb}$ tetramers dissociate into $\alpha /$ non- $\alpha$ dimers, which are small enough to filter through the glomerulus and pass out into the urine (haemo- globinuria). $\mathrm{Hb}$ loss is accompanied by iron loss and may cause iron deficiency. Some of the filtered $\mathrm{Hb}$ is reabsorbed by the proximal tubular cell, where it is degraded, and the iron is packaged as haemosiderin. Tubular cells have a rapid turnover and these slough off into the urine. Haemosiderinuria is detected by microscopic viewing of a slide prepared from urine sediment. Iron present in tubular cells stains deep blue with the prussian blue iron stain.

Folic acid and carbonic anhydrase molecules are small enough to filter through the glomerulus and pass out into urine. A third of total body folic acid is stored in red cells; therefore, ongoing haemolysis is likely to cause megaloblastic anaemia secondary to folate loss and deficiency. Similarly, loss of

Table 1. Intra- v. extravascular haemolysis: medium- to long-term clinical effects

\begin{tabular}{lll}
\hline Clinical effects & Intravascular haemolysis & Extravascular haemolysis \\
\hline $\begin{array}{l}\text { Haemoglobinuria/ } \\
\text { haemosiderinuria } \\
\text { Jaundice }\end{array}$ & Yes & No \\
Substrate deficiency & No & Iron, folic acid, zinc \\
Bony abnormalities & $\begin{array}{l}\text { Yes, e.g. frontal bossing, } \\
\text { maxillary hyperplasia }\end{array}$ & $\begin{array}{l}\text { Folic acid } \\
\text { Yes, e.g. frontal bossing, } \\
\text { maxillary hyperplasia }\end{array}$ \\
Splenomegaly & Yes (medium/long-term) & Yes (medium/long-term) \\
Gallstones & Less frequent & Yes \\
Iron overload & No & Yes \\
Leg ulcers & Yes & Yes \\
Pulmonary hypertension & Common, earlier onset (from & Less common, late onset \\
& second decade onwards) &
\end{tabular}




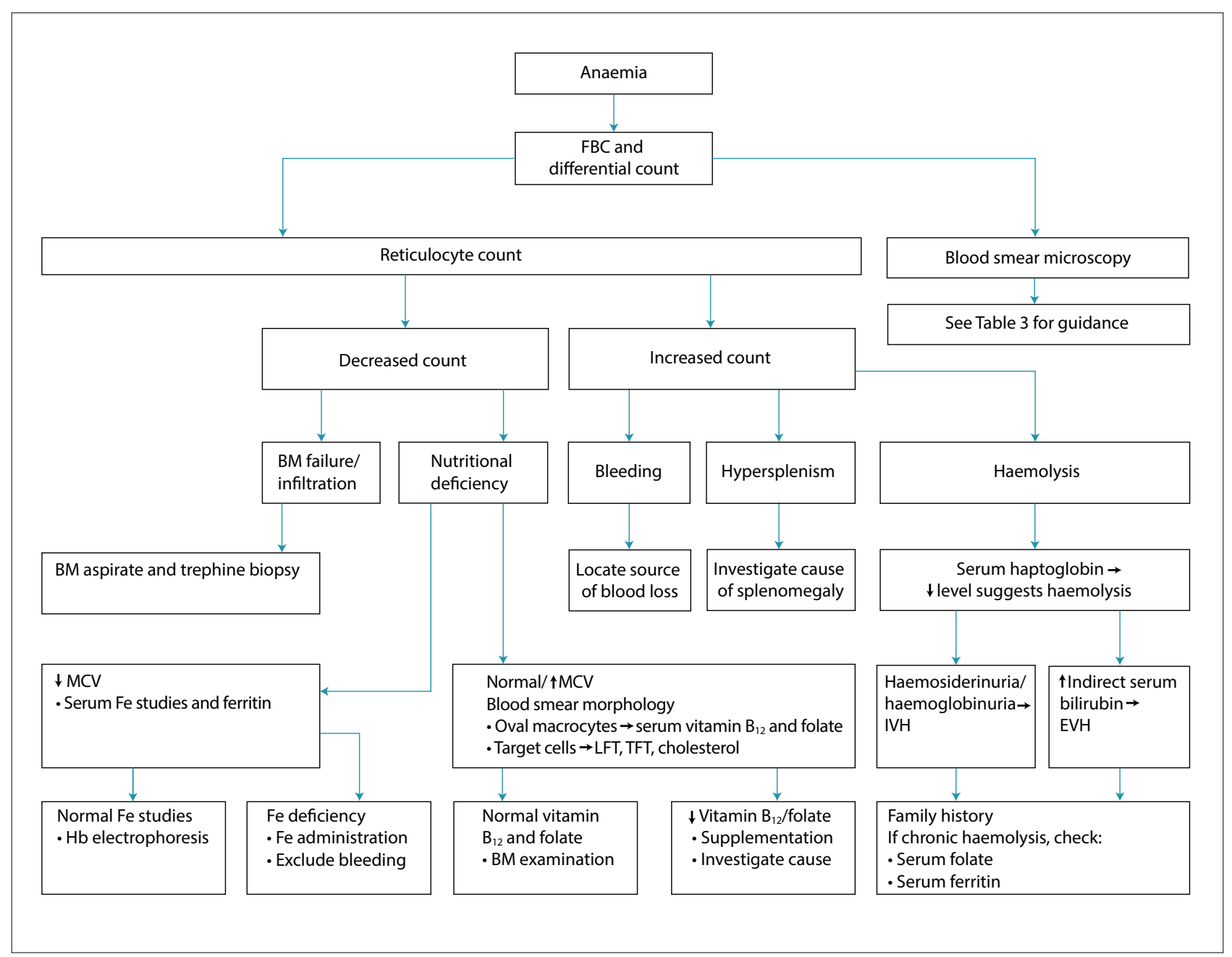

Fig. 1. Algorithm depicting a diagnostic approach to anaemia. $(F B C=$ full blood count; $B M=$ bone marrow; $T F T=$ thyroid function test; $L F T=$ liver function test; $M C V=$ mean cell volume; $F e=$ iron; $E V H=$ extravascular haemolysis.)

carbonic anhydrase, a metallo-enzyme that contains zinc, could lead to zinc deficiency.

The red cell membrane comprises a large meshwork of interconnected lipoproteins, and is therefore unable to be filtered through the kidneys. Massive intravascular haemolysis (IVH) (e.g. immediate blood transfusion reaction) frequently results in obstruction of glomerular capillaries and may cause pre-renal renal failure.

\section{Extravascular haemolysis}

Red cells are haemolysed within the macrophage and its contents released into the cytosol. The haem component of $\mathrm{Hb}$ is enzymatically transformed to bilirubin, which is then released into the circulation. As unconjugated bilirubin is water insoluble, it is bound to albumin and the complex is finally absorbed by hepatocytes, where it is conjugated and excreted through the biliary system.

As there is no mechanism to release excess iron, it continues to accumulate over the duration of haemolysis. Folic acid is also released into the circulation, but much of it is lost through the kidneys.

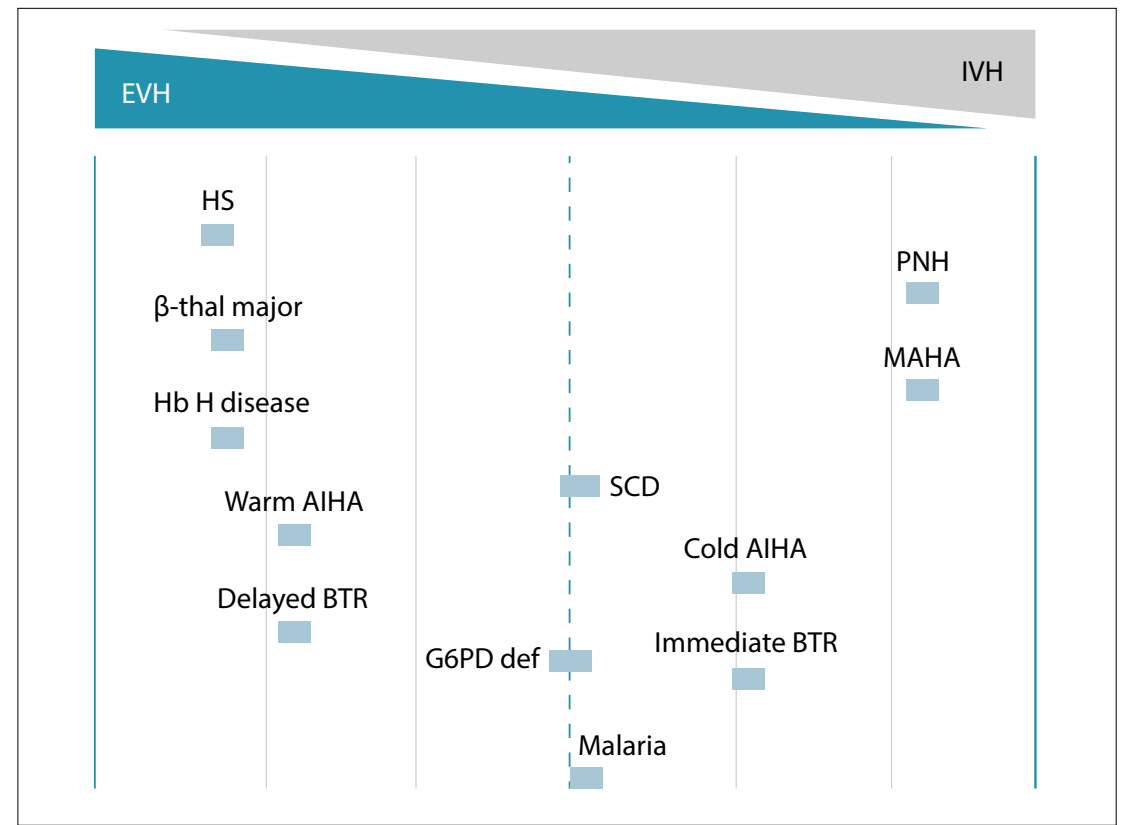

Fig. 2. Examples of haemolytic conditions with varying degrees of IVH and EVH. (HS = hereditary spherocytosis; $S C D=$ sickle cell disease; $A I H A=$ autoimmune haemolytic anaemia; $B T R=$ blood transfusion reaction; $M A H A=$ micro/macro-angiopathic haemolytic anaemia; $P N H=$ paroxysmal nocturnal haemoglobinuria; G6PD def = glucose-6-phosphate dehydrogenase deficiency; thal = thalassaemia .) 
Clinical manifestations and complications of chronic IVH and extravascular haemolysis $(\mathrm{EVH})$ are summarised in Table 1.

It should be noted that haemolysis is seldom purely intravascular or extravascular. In instances where both IVH and EVH exist, the clinical picture is determined by the predominant type of haemolysis. Examples of conditions that cause haemolysis are summarised in Fig. 2.

\section{Laboratory tests for haemolysis}

The most sensitive laboratory indicator of haemolysis is a decreased haptoglobin level. Available tests for haemolysis are summarised in Table 2.

\section{Diagnostic approach to haemolysis \\ Clinical approach}

A detailed history is essential, including duration and frequency of symptoms, age of onset, blood transfusions and family history. Inherited varieties generally present during early childhood.

Patients with homozygous beta thalassaemia become progressively anaemic during the first few months of infancy and present at the age of $\sim 3-6$ months with severe anaemia. During the third trimester of pregnancy ( 27 - 30 weeks), a switch from $\mathrm{Hb} \mathrm{F}$ to $\mathrm{Hb}$ A production begins. Owing to non-functioning beta globin genes, there is no beta globin chain expression and therefore no $\mathrm{Hb}$ A production to substitute the gradual decline of $\mathrm{Hb} \mathrm{F}$. This results in a gradual but progressive drop in $\mathrm{Hb}$ during the first few months of infancy.

Patients with sickle cell disease (SCD) have a unique mode of presentation. The hallmark of SCD is an acute pain crisis, most commonly affecting long bones, although any site/organ may be affected. Severe pain is experienced at the site of vaso-occlusion. Dactylitis (pain crisis in the bones of the hands and feet) is often the presenting symptom of SCD in early childhood. ${ }^{[3]}$

Glucose-6-phosphate dehydrogenase (G6PD) deficiency is inherited in an X-linked fashion and therefore typically manifests in males, although homozygous females are occasionally encountered. The haemolysis is most commonly episodic, following exposure to oxidant compounds, e.g. antimalarial drugs or sulphonamides. At birth, neonatal jaundice is common and may require intervention with ultraviolet light or exchange transfusion in more severe cases.

Of the red cell membrane disorders, hereditary spherocytosis is the most common variety. It presents with the classic triad of anaemia, jaundice and splenomegaly. The red cells are destroyed in the macrophages of the spleen, i.e. they undergo EVH.

In chronic haemolytic states, e.g. thalassaemia major or intermedia, splenomegaly and bony abnormalities, such as frontal bossing, develop at an early age and are usually a sequel to inadequate management or poor patient compliance. ${ }^{[4]}$

\section{Laboratory approach}

A full blood count, differential count, reticulocyte count and microscopic blood smear examination serve as baseline tests from whence further investigations are performed (Fig. 1). If haemolysis is suspected, it should be confirmed with a low haptoglobin level, which typically decreases during an haemolytic episode. Haptoglobin is a sensitive indicator of IVH and EVH. It should, however, be noted that haptoglobin levels may also decrease in liver disease (due to decreased synthesis) and rise in inflammatory states or malignancy (as it is an acute-phase reactant). ${ }^{[5]}$ Peripheral blood smear microscopy (May-Grünwald-Giemsa and reticulocyte preparations) often provides the diagnosis or additional clues for further investigation (Table 3). Reticulocytes, Heinz bodies and $\mathrm{Hb} \mathrm{H}$ inclusions in red cells can be detected through microscopic examination of smears prepared from reticulocyte preparations (peripheral blood incubated with brilliant cresyl blue for 20 minutes). Newergeneration blood cell counting analysers have the ability to enumerate reticulocytes.

\section{Fragmentation \\ haemolysis}

Fragmentation haemolytic anaemias occur as a result of disturbances in blood flow, either in large (macroangiopathic haemoly-

Table 2. Tests for intra- and extravascular haemolysis

\begin{tabular}{lll}
\hline Test & Intravascular haemolysis & Extravascular haemolysis \\
\hline Serum haptoglobin & $\downarrow$ & $\downarrow$ \\
Plasma Hb & Present & Absent \\
Haemoglobinuria & Present & Absent \\
Haemosiderinuria & Present & Absent \\
Serum lactate dehydrogenase & $\uparrow$ & $\uparrow$ \\
Serum unconjugated bilirubin & Normal & $\uparrow$
\end{tabular}

sis) or small (microangiopathic haemolysis) blood vessels. They are characterised by the presence of varying numbers of red cell fragments in the peripheral blood and accompanying thrombocytopenia in microangiopathic haemolysis.

Causes of macroangiopathic haemolysis include prosthetic heart valves, arteriovenous malformations and aortic stenosis. The anaemia is typically not severe, and active management is usually not required.

Microangiopathic haemolysis is caused by small-vessel obstruction by microthrom$\mathrm{bi}$, the distribution of which determines the organ system predominantly involved. Causes of microangiopathic haemolytic anaemia (MAHA), their associations and the specific clinical and laboratory derangements seen with each entity are summarised in Table 4. Several are pregnancy associated, and can be difficult to differentiate in the peripartum setting.

Thrombotic thrombocytopenic purpura (TTP) is an important cause of MAHA in South Africa (SA), as it is relatively common in HIV-positive patients. It carries a high mortality in the event of a missed diagnosis $(\sim 90 \%),{ }^{[6]}$ but with appropriate management survival is excellent $(\sim 80 \%) .{ }^{[7]}$ Other causes include autoimmune disease, a variety of drugs (including clopidogrel, ticlodipine and quinine) and congenital deficiency of ADAMTS13 (a metalloproteinase that cleaves high molecular weight Von Willebrand factor). HIV remains the most common cause in SA. TTP is characterised by a pentad of features: fragmentation haemolysis, thrombocytopenia, fever, renal failure (usually not severe), and fluctuating neurological derangement (including confusion or psychiatric manifestations, seizures and focal signs). However, all five features are not invariably present, and a presumptive diagnosis of TTP is made when there is MAHA and thrombocytopenia, with exclusion of all other causes of a thrombotic microangiopathy (e.g. disseminated intravascular coagulation). In the developed world, much emphasis is placed on the importance of documenting ADAMTS13 levels in the diagnosis of TTP, where its activity is reportedly consistently low $(<10 \%)$ in congenital and autoimmune-mediated TTP, but normal or more modestly reduced in other microangiopathies. ${ }^{[7]}$ However, ADAMTS13 levels are not universally low in HIV-associated TTP, which places the use of this test in question in the SA context. ${ }^{[8]}$ Furthermore, ADAMTS13 testing is not universally available in SA, and it is therefore not routinely recommended.

Although the gold standard of treatment for TTP is plasma exchange, large-volume fresh frozen plasma may suffice in some 
Table 3. Red cell morphological characteristics and interpretation

\begin{tabular}{|c|c|c|}
\hline Morphological observation & Differential diagnosis & Further test/s indicated \\
\hline $\begin{array}{l}\text { Target cells with microcytosis and/or } \\
\text { hypochromia }\end{array}$ & $\begin{array}{l}\text { Iron deficiency } \\
\text { Thalassaemia trait } \\
\text { Anaemia of chronic disorder }\end{array}$ & Iron studies, $\mathrm{Hb}$ electrophoresis \\
\hline Oval macrocytes, right shift & Megaloblastic anaemia & Vtimain $B_{12}$ and folic acid levels \\
\hline Round macrocytes with target cells & $\begin{array}{l}\text { Possible liver disease } \\
\text { Hypothyroidism } \\
\text { Hyperlipidaemia }\end{array}$ & $\begin{array}{l}\text { Liver function and thyroid function tests, } \\
\text { lipid profile }\end{array}$ \\
\hline Sickle cells & Sickle cell disease & $\begin{array}{l}\mathrm{Hb} \text { electrophoresis: to confirm presence of } \\
\mathrm{Hb} \mathrm{S} \text { and check } \mathrm{Hb} F \text { level }\end{array}$ \\
\hline Spherocytes & $\begin{array}{l}\text { Hereditary spherocytosis } \\
\text { Warm AIHA }\end{array}$ & $\begin{array}{l}\text { Gamma Coombs test: positive in } \\
\text { warm AIHA } \\
\text { Red cell membrane analysis } \\
\text { Autoimmune screening }\end{array}$ \\
\hline Elliptocytes & Hereditary elliptocytosis & Red cell membrane analysis \\
\hline $\begin{array}{l}\text { Severe anisopoikilocytosis, diffuse/punctate } \\
\text { basophilia, red cell fragmentation }\end{array}$ & $\begin{array}{l}\text { Hereditary pyropoikilocytosis } \\
\text { Thalassaemia major }\end{array}$ & $\begin{array}{l}\text { Red cell membrane analysis, } \\
\mathrm{Hb} \text { electrophoresis }\end{array}$ \\
\hline Coarse basophilic stippling & $\begin{array}{l}\text { 5'PNT deficiency } \\
\text { Glycolytic pathway enzyme deficiency } \\
\text { Lead poisoning }\end{array}$ & $\begin{array}{l}\text { Plasma lead levels, red cell } \\
\text { 5'PNT assay, analysis of glycolytic pathway } \\
\text { enzymes }\end{array}$ \\
\hline Autoagglutination & Noted in cold AIHA & $\begin{array}{l}\text { Non-gamma Coombs test: positive in } \\
\text { cold AIHA }\end{array}$ \\
\hline Red cell fragmentation & $\begin{array}{l}\text { Decreased platelet count } \rightarrow \text { microangiopathic } \\
\text { haemolysis } \\
\text { Normal platelet count } \rightarrow \text { macroangiopathic } \\
\text { haemolysis }\end{array}$ & See Table 4 \\
\hline Malaria & Plasmodium falciparum life-threatening infection & $\begin{array}{l}\text { Identify species } \\
\text { Monitor FBC and parasite count during } \\
\text { treatment }\end{array}$ \\
\hline $\begin{array}{l}\text { Heinz bodies (reticulocyte preparation) } \\
\text { Bite cells (May-Grünwald-Giemsa } \\
\text { preparation) }\end{array}$ & $\begin{array}{l}\text { G6PD deficiency } \\
\text { Exposure to oxidant compounds } \\
\text { Unstable } \mathrm{Hb}\end{array}$ & $\begin{array}{l}\text { Oxidant drug or toxin history, check red cell } \\
\text { G6PD level }\end{array}$ \\
\hline $\mathrm{Hb} \mathrm{H}$ inclusions & Present in alpha thalassaemia & $\begin{array}{l}\text { Hb electrophoresis, PCR for alpha } \\
\text { thalassaemia }\end{array}$ \\
\hline
\end{tabular}

patients. Corticosteroids should also be initiated at diagnosis, and HIV-seropositive patients should receive concomitant combination antiretroviral therapy, irrespective of their CD4 count. The lactate dehydrogenase level and platelet count are used to monitor response to treatment. Importantly, TTP is a relative contraindication for platelet transfusion, as this may fuel the microthrombotic process. However, platelets should not be withheld in the event of significant bleeding. Patients with TTP should be referred to and managed by specialist haematologists.

\section{Bleeding}

Anaemia due to acute bleeding usually occurs after substantial blood loss and is most often encountered in patients with a bleeding diathesis, or in trauma, postoperative or obstetric settings. In the hyperacute phase of bleeding, the anaemia is usually normocytic and normochromic. This is followed by macrocytosis due to a reticulocyte response that develops over 2-3 days. Chronic low-volume blood loss causes a microcytic anaemia without an elevation of the reticulocyte production index (RPI) (due to iron deficiency). Where the source of the blood loss is not obvious, the following investigations may be helpful: (i) stool analysis for faecal occult blood; (ii) urine dipstix and microscopy for haemoglobinuria and detection of red cells, respectively; (iii) gynaecological review; and (iv) examination of sputum for iron-laden macrophages (detected in pulmonary haemosiderosis due to intra-alveolar bleeding).

\section{Hypersplenism}

Hypersplenism refers to an enlarged spleen with sequestration or destruction of blood cells, which leads to the development of anaemia and/or neutropenia and/or thrombocytopenia. It is characterised by a hypercellular bone marrow response and improvement after splenectomy. There may be some degree of associated haemolysis. 
Table 4. Summary of common microangiopathic haemolytic anaemias

\begin{tabular}{|c|c|c|c|}
\hline Microangiopathic entity & Common features & Associations/risk factors & Management \\
\hline TTP & $\begin{array}{l}\text { Anaemia and thrombocytopenia } \\
++ \text { red cell fragmentation } \\
\text { + renal impairment } \\
\text { Fever } \\
\text { Fluctuating neurological manifestations } \\
\text { ADAMSTS13 levels may be low }\end{array}$ & $\begin{array}{l}\text { HIV infection } \\
\text { Autoimmune disease } \\
\text { Drugs (clopidogrel, ticlodipine, } \\
\text { quinine) } \\
\text { Metastatic adenocarcinoma } \\
\text { Allogeneic stem cell/solid organ } \\
\text { transplantation } \\
\text { Congenital deficiency of } \\
\text { ADAMTS13 (rare) }\end{array}$ & $\begin{array}{l}\text { Plasma exchange } \\
\text { Steroids }\end{array}$ \\
\hline DIC & $\begin{array}{l}\text { Anaemia and thrombocytopenia } \\
+ \text { red cell fragments } \\
\text { Deranged coagulogram ( } \uparrow \text { INR and/or PTT, } \\
\uparrow D \text {-dimers, } \downarrow \text { fibrinogen and AT levels) }\end{array}$ & $\begin{array}{l}\text { Major trauma } \\
\text { Sepsis } \\
\text { Obstetric accidents }\end{array}$ & $\begin{array}{l}\text { Treat underlying cause } \\
\mathrm{FFP} / \text { cryoprecipitate infusion } \\
\mathrm{LMWH}^{*} \\
\text { Platelet infusion if bleeding }\end{array}$ \\
\hline HUS & $\begin{array}{l}+/++ \text { red cell fragments } \\
\text { Marked renal impairment } \\
\text { Moderate anaemia and thrombocytopenia } \\
\text { Complement } 3 \text { and } 4 \text { levels may be low in } \\
\text { aHUS }\end{array}$ & $\begin{array}{l}\text { Shiga toxin-associated diarrhoeal } \\
\text { illness } \\
\text { Shigella dysenteriae } \\
\text { Escherichia coli (O157:H7 and } \\
\text { O104:H4) } \\
\text { aHUS dysregulation of alternate } \\
\mathrm{C}^{\prime} \text { pathway } \\
\text { Congenital factor H or I deficiency } \\
\text { Antibodies to factor H }\end{array}$ & $\begin{array}{l}\text { Supportive measures } \\
\text { A trial of plasma exchange } \\
\text { for aHUS } \\
\text { Eculizumab (limited } \\
\text { availability) } \\
\text { Dialysis, usually for aHUS }\end{array}$ \\
\hline $\begin{array}{l}\text { HELLP syndrome/pre- } \\
\text { ecclampsia }\end{array}$ & $\begin{array}{l}\text { Anaemia and thrombocytopenia } \\
+ \text { red cell fragments } \\
\text { Raised AST/ALT } \\
\text { Hypertension } \\
\text { Headache and visual disturbance, RUQ pain, } \\
\text { pulmonary oedema }\end{array}$ & $\begin{array}{l}\text { Risk of recurrence in subsequent } \\
\text { pregnancies }\end{array}$ & $\begin{array}{l}\text { Emergency delivery by } \\
\text { caesarean section }\end{array}$ \\
\hline
\end{tabular}

The spleen functions as a reservoir for blood cells and a filter that removes senescent, abnormal or antibody-coated red cells from the circulation. When it is enlarged, these functions are amplified; therefore, red cell survival is somewhat attenuated and the number of cells sequestered is increased. This may result in mild to moderate reductions in red cell, white cell and/or platelet counts, as well as biochemical evidence of haemolysis.

Hypersplenism may occur in any patient with splenomegaly, regardless of the cause, including portal hypertension, infectious causes (such as chronic malaria), chronic haemolytic states, or haematological malignancies. A peripheral blood smear review is routinely indicated in patients with splenomegaly, and bone marrow examination in instances where the cause for the splenomegaly is not readily apparent.

Where anaemia is caused by hypersplenism alone, i.e. without an underlying cause, the red cells are usually normocytic and normochromic. The reticulocyte count and RPI are usually raised, but may be lower than anticipated owing to sequestration of reticulocytes in the spleen. In patients with portal hypertension, anaemia is often microcytic and hypochromic because of iron deficiency from chronic blood loss, e.g. bleeding oesophageal varices, haematuria or gastrointestinal bleeding in chronic schistosomiasis. The latter is not an uncommon cause of portal hypertension in SA.

\section{Conclusion}

Causes of anaemia are numerous and varied. Owing to its manifestation in a wide variety of conditions, investigating the cause requires a thorough history, physical examination and systematic laboratory and ancillary investigations.

1. World Health Organization. The Global Prevalence of Anaemia in 2011. Geneva: WHO, 2015

2. Alli N, Vaughan J, Patel M. Anaemia: Approach to diagnosis. S Afr Med J 2017;107(1):23-27. http://

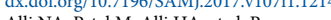

mendations for the management of sickle cell disease in South Africa. S Afr Med 2014 /

herall DJ. Clinical aspects of $\beta$ thalassaemia. In: Steinberg MH, Forget BG, Higg DR, Nagel RL eds. Disorders of Hemoglobin, Genetics, Pathophysiology and Clinical Management. Cambridge: Cambridge University Press, 2001.

5. Means RT Jr, Glader B. Anaemia: General considerations. In: Greer IP, Arbor DE, Glader B, et al., eds. Means RT Jr, Glader B. Anaemia: General considerations. In: Greer JP, Arbor
Wintrobe's Clinical Hematology. 13th ed. Philadelphia: Wolters Kluwer, 2013.

6. Amorosi EL, Ultmann JE. Thrombotic thrombocytopenic purpura: Report of 16 cases and review of Amorosi EL, Ultmann JE. Thrombotic thrombocytopenic purpura: Report of 16 cases and review of
the literature. Medicine 1966;45(2):139-159. http://dx.doi.org/10.1097/00005792-196603000-00003 the literature. Medicine 1966;45(2):139-159. http://dx.doi.org/10.1097/00005792-196603000-00003 Scully M, Goodship T. How I treat thrombotic thrombocytopenic purpura and atypical ha
uraemic syndrome. Br J Haematol 2014;164(6):759-766. http://dx.doi.org/10.1111/bjh.12718

8. Gunther K, Garizio D, Nesara P. ADAMTS13 activity and the presence of acquired inhibitors in human immunodeficiency virus-related thrombotic thrombocytopenic purpura. Transfusion 2007;47(9):1710-1716. http://dx.doi.org/10.1111/j.1537-2995.2007.01346.x 